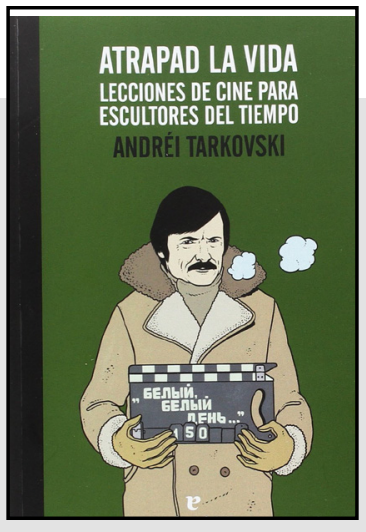

Atrapad la vida: lecciones de cine para escultores del tiempo

Andréi Tarkovski

Errata Naturae, Madrid, 2017

\title{
Tarkovsky y el tiempo jamás perdido
}

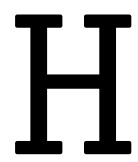

onoré Balzac, Stendhal, Émile Zola, Benito Pérez Galdós... Muchos son los escritores que se sumaron al realismo y el naturalismo en el siglo XIX como una búsqueda de plasmar la realidad tal y como era, con sus luces y sus sombras, lejos de la exaltación pasional y los recursos del romanticismo. Para Zola, el determinismo de los ambientes de los personajes describió a la perfección la idea de la novela como mecanismo para descubrir el futuro de aquellos que respondían a sus parámetros. Sus narradores omniscientes, con su deseo de desaparecer como (en una metáfora posmodernista) si solo fueran una cámara filmando sin tomar ningún tipo de juicio, sería lo que autores como Gustave Flaubert definirían como un autor que debe ser, en su obra, como Dios en el universo, presente en todas partes y visibles en ninguna. Seguramente, el director Andréi Tarkovski hubiese estado de acuerdo en este aspecto, dada su capacidad para la cita de Chéjov, Dostoievski y Tolstoi, entre otros autores rusos unidos al realismo, y su capacidad para intentar captar la importancia del tiempo a lo largo de su carrera cinematográfica.

El violín y la apisonadora (1961), La infancia de Iván (1962), Andrei Rublev (1966), Solaris (1972), El espejo (1975), Stalker (1979), Nostalgia (1983) y Sacrificio (1986) son los títulos que componen la filmografía en solitario de un director y escritor como Tarkovski, siempre profuso en la densidad y en ofrecer al espectador la oportunidad 
de dar, cada uno, una respuesta a estas cintas, cuya finalidad eran captar el tiempo y el drama de unos personajes complejos. Todo su punto de vista del cine como obra ética y artística se vislumbra a través de los pasajes de su obra teórica, donde daba importancia a la idea primigenia del film.

La idea debe tener la misma consideración que un acto de carácter ético. Del mismo modo que un libro, antes que nada, es una acción, un hecho moral y no sólo artístico. Espero que entendáis de que estoy hablando. Están los que escriben y los escritores, son dos cosas distintas (Tarkovsky, 2017:110).

Atrapad la vida es, junto a Esculpir en el tiempo, su segunda obra teórica más importante, donde el director nos ofrece su perspectiva del mundo del cine, no solo desde su punto de vista, sino ofreciendo argumentaciones basadas en las obras de destacados escritores como el ya citado Fiódor Dostoievski, directores como Ingmar Bergman e incluso filósofos como Hegel. Y es que, si buscásemos a uno de los grandes pensadores del cine, sin duda, tendríamos en Tarkovski a uno de sus emblemas por su capacidad para compendiar todas las disciplinas artísticas que conjugan su propia cosmovisión.

Lo editores de Atrapad la vida, en la colección La muchacha de dos cabezas de Errata naturae, recalcan la importancia de Tarkovski y sus libros sobre cine, rescatando esta obra inédita en nuestro país y que sería el germen del segundo Esculpir en el tiempo, que en nuestro país solo ha contado con traducciones desde el alemán y no desde el ruso (concibiendo una serie de errores perdidos en la traducción). A su vez, Atrapad la vida se compone de una serie de ensayos que se vertebran en torno a uno mayor que da título al libro. Un encuentro con el tiempo, La imagen de la vida, Los guionistas no existen, La película y el secreto y Desmontar el montaje se convierten en trabajos donde Tarkovski plasma sus ideales sobre la concepción del cine en todos sus aspectos. No es solo un manual filosófico sobre cómo rodar o qué es el cine, sino que también se ocupa sus creencias sobre los diversos aspectos que componen una película.

En sus palabras, el cine puede ser un espacio perfecto para la experimentación, pero una vez se conozcan las leyes. De ahí que proponga proyectos más asumibles 
hoy que cuando escribió esta obra, como crear una gran película en torno a la vida y la muerte de una persona de la cual se ha filmado todo momento. A partir de ahí, varios directores trabajarían con el mismo material cinematográfico para crear su propia película. De ahí, Tarkovski define la importancia de la voz propia en la gran pantalla.

El director de Solaris apunta la importancia de la idea del director y cómo este tampoco se debe sentir obligado a compartirla para evitar que cada una de las piezas de un rodaje realice su propia versión y no la del director.

Es decir, al final os encontraréis desempeñando el papel de alguien que es testigo de cómo escribe el guionista, de cómo interpreta el actor, de cómo filma el operador de cámara, de cómo construye el decorado el escenógrafo y de cómo edita el montador. Ya no tendréis nada que ver con ello, aunque al principio tuvierais una idea propia. Pero eso fue en un primer momento. Antes de que se escribiera el guion y se hiciera todo lo demás. Es difícil proteger la propia idea para que no acabe «despedazada» por el operador de cámara, el director de arte, los actores, el compositor o por todos a un tiempo (Tarkovsky, 2017:116).

Como el cine de Tarkovski, su prosa puede llegar a estar marcada por un compromiso y una densidad que llevan al lector a la reestructuración de su pensamiento y su sistema de creencias según una forma artística tan compleja como el cine. Cualquiera que se haya puesto alguna vez detrás de una cámara, comprenderá la dificultad de llevar a buen puerto una creación $\mathrm{y}$, de ahí, que una buena película pudiera definirse como un milagro a veinticuatro fotogramas por segundo y, en el caso de Tarkovski, halla en este milagro un modo de entender el mundo particular, personalísimo, pero, a la vez, también universal para colmar el espíritu del espectador.

El cine de Tarkovsky busca, como recoge en este volumen, una forma de captar los acontecimientos mediante imágenes cinematográficas, sin ser una fría reproducción documental. Para ello, también recurre a los haikus como modo de representar su deseo de expresar fuertes sentimientos a través de imágenes. 
Además, en Atrapad la vida, repasa también cómo fue hacer algunas de sus películas: que quería representar con determinado plano o qué cambiaría de alguna de sus cintas. Es interesante la alusión o la obra de Leonardo Da Vinci Retrato de mujer joven ante un enebro y la protagonista de El espejo, Margarita Térejova, con la que pretendía mostrar lo encantador y lo repugnante en un mismo film. Es, por esto, por lo que resulta un título no solo interesante para directores, estudiantes e investigadores del mundo del séptimo arte, sino también para todos los admiradores de la obra del director soviético, que defendía el cine como un arte independiente, que no debía volverse deudor de otros (rechazaba, por ejemplo, la creación de personajes al estilo literario, considerando que era imposible lograr lo que habían logrado autores como Shakespeare, Pirandello, 0strovsky y Ben Jonson, mostrándose más como tipologías o ideas que como personajes trasladables al mundo fílmico). Por supuesto, el director también habla de sus "fracasos" en sus conocidas películas:

En Solaris me pareció que era indispensable rodar una escena con una mirada no humana, o renunciando a una percepción típicamente humana. Me refiero a la escena del intento de suicidio de Hari y de su gradual recuperación. Sin embargo, de aquello no salió nada. Fue imposible filmarlo, pues cualquier estilización semejante no favorece la creación de una imagen, sino sólo una suerte de sistema lógico de demostración (Tarkovsky, 2017:95).

Por otra parte, leer Atrapad la vida supone un interesante repaso por el mundo del cine en su tiempo, pero también por la creación fílmica dentro de la Unión Soviética, la cual dependía del Goskino, la Comisión Cinematográfica del Estado Soviético.

Puede que algunos lectores no comprendan el armamento filosófico de un autor que no duda cargar hacia el cine industrial y el cine poético con la misma contundencia. Otros acusarán a algunas de las afirmaciones de Tarkovski de contradictorias o polémicas (como esa defensa de que los guionistas no existen) o de esnobs (donde se juzga, desde su filosofía, qué es cine y qué no). No obstante, si uno se dispone a leer con completa libertad estas palabras, sin prejuicios, y apreciando el conocimiento cinematográfico y cultural de Tarkovski, donde su humildad le hace 
reconocer sus aprendizajes (como pasó de rechazar el color a aceptarlo, por ejemplo), hallará en el autor nacido en Zavrazhie a uno de los teóricos fílmicos más importantes del siglo XX. Y es que decía Tarkovski que "es terrible ver a un hombre de talento cansado de ser él mismo"; por fortuna, ya sea a través de su cine o su obra teórica, el espectador o el lector jamás siente que ese fuera el caso del director.

\section{Carlos Javier Eguren Hernández}

Investigador

Universidad de La Laguna

España

\section{(c) $)(1)(9)$}

Esta obra está bajo una licencia de Creative Commons Reconocimiento-NoComercial 4.0 Internacional. 